\title{
Obituaries
}

\section{Matthew Arnum Barnor}

Physician who played a leading role in the development of Ghana's health service

Matthew Arnum Barnor was one of the most influential figures in Ghana's medical profession, and had a leading role in the development of the country's health service after independence. He founded a hospital, was a former president of the Ghana Medical Association, and helped set up the Planned Parenthood Association of Ghana.

Born in Accra, in the then Gold Coast, in 1917, he won a British government scholarship to study medicine and left for Edinburgh University on the Belgian ship Copacabana during the second world war. It was one of seven ships travelling in a convoy over the Atlantic and it had several west African students on board. One of the other boats in the convoy was torpedoed, and the Copacabana's captain drafted the students into "submarine watch."

After qualifying and house jobs at the Western Infirmary, Edinburgh, Dr Barnor worked in Sunderland during the early years of the NHS before moving to London to study for the diploma in tropical medicine and hygiene.

In 1950 he joined the Gold Coast Colonial Medical Service. In those days Africans who successfully completed their medical training were posted to deprived areas of the country. After being employed as medical officers, they were put on probation for three years. All senior servants, including

\section{Advice}

We will be pleased to receive obituary notices of around 250 words. Pressure on space means that in most cases we will be able to publish only about 100 words in the printed journal, but we can run a fuller version on our website. We will take responsibility for shortening. We do not send proofs. Good quality, original photographs are welcome. Please give a contact telephone number and, where possible, supply the obituary on a diskorbyemail to obituaries@bmj.com If sending a picture electronically, please attach as a jpeg or a tiff rather than as part of a Word document. We need to know the year of birth and exact date of death of the deceased, and we prefer obituaries to state the cause of death. Please spell out abbreviations.

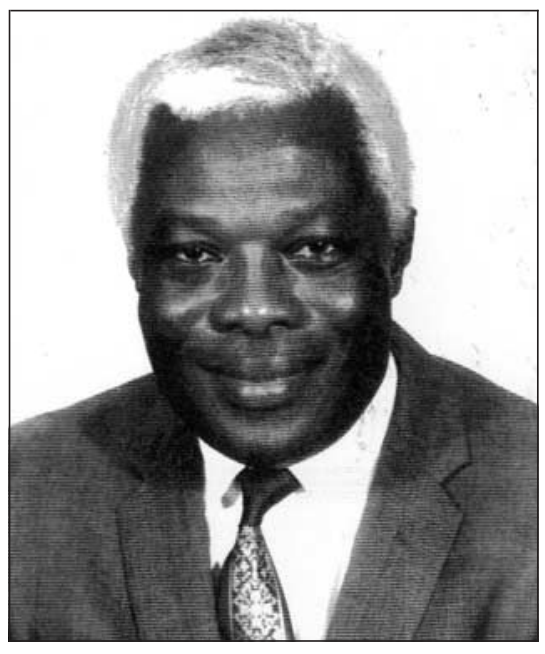

Africans, were on equal salaries if they occupied identical positions. The difference was that the Europeans received an expatriate allowance and worked in the European Hospital. The crown employed the first Ghanaian doctor in 1887. The next Ghanaian doctor was not appointed until 1926. In 1949 the Gold Coast was on the verge of a representative form of government. There were a total of 84 doctors, of whom only 17 were Gold Coast Africans, and the remainder expatriate Europeans.

After independence in 1957 Dr Barnor retired from the government service. He had served in each of the nine district regions in Ghana and he realised the need to be in Accra.

In 1958 he set up the Link Road clinic, Accra, which assumed hospital status in 1972. It was a fine hospital that still functions, offering both primary care services and secondary care services in a fee paying facility.

Dr Barnor was instrumental in founding the Ghana Medical Association (GMA), and was elected honorary first secretary of the GMA in 1958. He was president of the GMA from 1963 to 1966, during which he steered the association through some stormy waters.

He also turned his attention to medical education. In 1962 he was a member of the interim council of the medical school before its conversion to a faculty of the University of Ghana. He lectured on professional responsibility and ethics for the first 10 years of the school's existence.

Dr Barnor co-founded the Planned Parenthood Association of Ghana in 1967, working with the International Planned Parenthood Association. He was the first vice president and general adviser until 1985.

His high position in the GMA and other professional bodies brought him into some tough situations with Ghana's first president, Kwame Nkrumah, and subsequently with General Kutu Acheampong and government ministers of other Ghanaian regimes. His medical colleagues, however, greatly trusted him as he deliberately steered an apolitical course.

He was the chairman of the management committee of the University of Ghana Legon Hospital, which catered for staff and students of Ghana's first university. $\mathrm{He}$ retired voluntarily in 1989 as a result of pressure from other commitments.

Dr Barnor retired from medical practice in 1994. He received many national and international awards, including, in 2003, fellowship of the West African College of Physicians. In April 2005 he was one of 10 doctors honoured with a Lifetime of Achievement Award by the government of Ghana and the Ghana Medical and Dental Council.

He never forgot his roots in Edinburgh and kept in touch with his colleagues, attending all the important reunions. His academic colleagues visited Ghana as lecturers and external examiners of the medical school in the early years.

He leaves a wife, Dorothy; five children; and 14 grandchildren. [E EvANs]

Matthew Arnum Barnor, former family physician, president Ghana Medical Association, founding father Planned Parenthood Association Ghana, founder Link Road Hospital, Accra, Ghana (born 1917; q Edinburgh 1947;DTME'H), d 20 June 2005.

Longer versions of these obituaries are available on bmj.com 


\section{Susan Field}

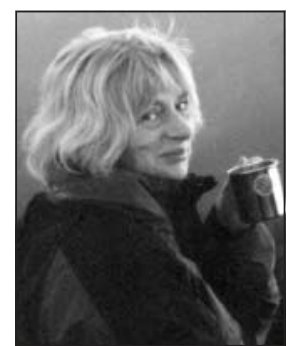

Medical officer Medical Foundation for the Care of Victims of Torture (b Leicester 1944; $q$ Queen's University, Belfast, 1970; MRCGP, DCH, DTME'H), died from cholangiocarcinoma on 22 September 2005.

Sue Field was a party animal with a highly developed social conscience. She worked as a ship's doctor on the Oriana, in the remote parts of Canada serving the Canadian Indian population, and in paediatrics in Barbados and Whakatane, New Zealand. Later she became a research fellow at Hughes Hall, Cambridge, and entered general practice in Saffron Walden. In 2000 she did the diploma in tropical medicine and health in preparation for work with Médecins Sans Frontières, but her attention was diverted by the plight of victims of torture seeking asylum in the United Kingdom. She leaves a husband, Jamie, and three children. [Graham Cresswell]

\section{Clement Grimshaw}

Former thoracic surgeon Oxford (b Batley, Yorkshire, 1915; q Edinburgh 1938; MA, FRCS, FRCS Ed), died from congestive heart failure on 25 August 2005.

After qualifying Clem Grimshaw did a year in general practice at the Royal Infirmary in Perth. Awaiting the call to national service, he took a temporary post in the obstetrical department at Hope Hospital, Salford, but after two surgeons died in the Blitz he was retained for general surgical duties. He later served in the Far East with the Royal Army Medical Corps. Clem was appointed as second consultant thoracic surgeon to the United Oxford Hospitals and the regional board in 1954 and retired at the age of 63 to enjoy more time in the company of his wife, Hilde, and four daughters. [LibBy GRIMSHAW]

\section{Isla Hayward (Mrs McGuire, née Greenlaw)}

Consultant anaesthetist Frimley Park Hospital, Surrey (b Bury 1928; q Royal Free Hospital, London, 1952; FFA RCS 1966), died from lung cancer on 7 June 2005.

Isla completed her house appointments at the new University Hospital, Kingston, Jamaica. She then joined the Federal Medical Service in Lagos, Nigeria, where she and her husband both contracted poliomyelitis. While in Lagos her interest in anaesthetics began. She returned to the Royal

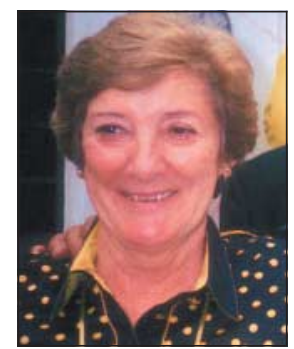

Free for specialist training and was appointed consultant to Farnham Hospital Group, later transferring to the new Frimley Park Hospital, where she established the intensive care unit. She leaves a husband, Neil; three sons from her first marriage; and eight grandchildren. [KeIth GReEnLAw]

\section{Chinnamma Jayakkar}

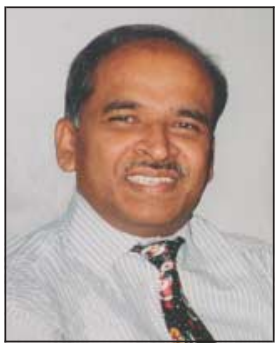

Medical rehabilitation officer Ellesmere Port Hospital (b Vakkom, Kerala, India, 1952;

$q$ Trivandrum Medical College 1977), died from a brain tumour on 23 September 2005.

Jayakkar came to the United Kingdom in 1982 and began his medical career in Rotherham. He then worked in the geriatric departments of Scunthorpe, Burnley, Doncaster, Chester, and Ellesmere Port hospitals. Jayakkar had a passion for music and cricket; his knowledge of the history of the game was astonishing. He leaves a wife, Jaya, and two children. [ANOOP JAYAKKAR, REMYA JAYAKKAR, ANGELINA Jayakumar, Sethu Jayakumar]

\section{John Keast-Butler}

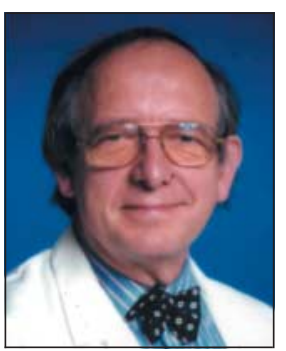

Consultant ophthalmologist Addenbrooke's Hospital, Cambridge, 1977-2002 (b London 1937; q Cambridge/University College Hospital, London, 1964; FRCS, FRCOphth), d 19 March 2005.

John Keast-Butler was big in stature and big in personality. Not only was he a meticulous clinician but also a master craftsman in an immense range of practical skills as manifested in the beautiful home and gardens that he and his wife, Brigid, created on the banks of the Cam. Among many appointments, he was director of studies in clinical medicine at Trinity College and honorary secretary of the Cambridge Medical Graduates' Club. John and Brigid were travelling in Goa earlier this year when he had a major fall that preceded a fatal pulmonary embolus. $\mathrm{He}$ leaves Brigid and three children. [DAvID WILLIAMS]

\section{Johanna Clara Joacomina Collis McLean}

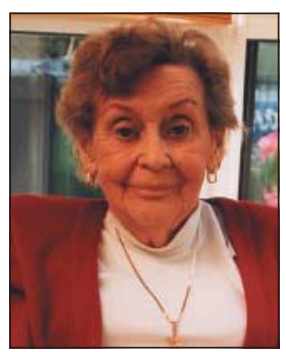

Former assistant medical officer Lagos, Nigeria (b 1919; q King's College Hospital, London, 1956), d 1 January 2005.

Hanna grew up in the Netherlands, where during the second world war she and her mother sheltered Jewish families. When Belsen was liberated in 1945 Hanna was invited by Robert Collis, paediatrician and member of the Red Cross, to set up a unit to care for 500 orphans within the campsite. She and Bob went on to work with refugees. Her experiences at Belsen plus the aftermath of the war made Hanna determined to read medicine. Following house jobs, she and Bob set up a cerebral palsy clinic. In 1962 after their marriage, the pair moved to Nigeria, where Hanna lectured at Lagos University, later becoming assistant medical officer. Predeceased by Bob and a son, and her second husband, Donald McLean, she leaves a son. [Uto HogerzeIL, Bryan ScaIfe] p+

\section{Tusevnambi Jayatissa Rajapaksa}

Former consultant in old age psychiatry St Edward's Hospital, Cheddleton, North Staffordshire (b Sri Lanka 1928; q Colombo 1952; MRCPsych), died from a brain tumour on 22 May 2005.

Raj first came to England in 1950 as a senior house officer in paediatrics in Cambridge, returning to Sri Lanka after two years to continue in general practice. He came back to England in 1965 for postgraduate studies at the Institute of Neurology, London, but his interest in psychological medicine led to a career change to psychiatry. Working as a senior registrar at City General Hospital, Stoke-on-Trent, he set up old age psychiatry services for North Staffordshire. In retirement he carried out voluntary work in Sri Lanka. Predeceased by his daughter, he leaves a wife, Chitra; two sons; and three grandchildren. [Roland Fernando, Ranjanie Fernando] 